\title{
KAJIAN TENTANG POLA ASUH ORANGTUA TERHADAP PERILAKU ANAK USIA DINI
}

\author{
Sintia Yapalalin1, Rosita Wondal2, Bujuna Alhadad ${ }^{3}$ \\ Universitas Khairun \\ Fakultas Keguruan dan Ilmu Pendidikan \\ Jl. Bandara Sultan Baabullah Kota Ternate Utara, Kotak Pos 53 Ternate 977328 \\ Telepon: (0921) 3110905-Faksimili 0921-3110901
}

\begin{abstract}
Abstrak: Pola asuh orangtua merupakan segala bentuk dan proses interaksi yang terjadi antara orangtua dan anak. Terdapat 3 jenis pola asuh yang dikaji dalam kajian literature ini yakni pola asuh otoriter (authoritarian), demokratis/autoritatif (authoritative), dan permisif (permissive). Adapun penelitian kajian literatur ini bertujuan untuk mengkaji jenis pola asuh manakah yang tepat diterapkan oleh orangtua dalam pengasuhan bagi anak. Dalam kajian literatur ini penulis dapat menyimpulkan beberapa hal yakni: 1) Pola asuh orangtua berpengaruh pada perilaku anak, 2) Setiap orangtua berhak memilih pola asuh yang tepat bagi anaknya dengan memperhatikan karakteristik anak, situasi dan kondisi yang dialami anak, namun dengan memperhatikan konsekuensi dari penerapan ketiga pola asuh orang tua, maka dianjurkan untuk orangtua agar menerapkan pola asuh demokratis bagi anak.
\end{abstract}

\section{Kata Kunci: Pola Asuh, Perilaku Anak}

Abstract: Parenting is all forms and interaction process that happen between parent and children. There are three types of parenting in library research consist of authoritarian, democratic and permissive. This study aims to review the types of parenting, which is appropriate applied by parents in parenting children. Based on this study the writer can conclude that : 1)the parenting types can impact on children behavior, 2) Every parent has the right to choose the approprite parenting to the children and concern about the characteristic of children, and the the children condition, with concern the concequences of aplying the three types of parenting. The parents is suggested to apply democratic parenting to the childrean.

Key words: Parenting, Children Behavior 


\section{A. Pendahuluan}

Pendidikan Anak Usia Dini (PAUD) adalah suatu upaya pembinaan yang ditujukan kepada anak sejak lahir sampai dengan usia 6 (enam) tahun yang dilakukan melalui pemberian rangsangan pendidikan untuk membantu pertumbuhan dan perkembangan jasmani dan rohani agar anak memiliki kesiapan dalam memasuki pendidikan lebih lanjut (Permendikbud No 146, 2014: 3). Hal tersebut merupakan upaya strategis untuk menyiapkan generasi bangsa yang berkualitas dalam rangka memasuki era globalisasi yang penuh dengan berbagai tantangan. Dalam PAUD anak sudah diajarkan tentang berbagai pengetahuan, anak diajarkan cara bersosialisasi, anak diajarkan perbuatan yang baik dan buruk dan lain sebagainya.

Pendidikan Anak Usia Dini (PAUD) diartikan sebagai jenjang pendidikan sebelum jenjang pendidikan dasar yang merupakan suatu upaya pembinaan yang ditujukan bagi anak sejak lahir sampai dengan usia enam tahun yang dilakukan melalui pemberian rangsangan pendidikan untuk membantu pertumbuhan jasmani dan ruhani agar anak memiliki kesiapan dalam memasuki pendidikan lebih lanjut yang diselenggarakan pada jalur formal, nonformal, dan informal (Hasan, 2009: 15). Pendidikan Anak Usia Dini (PAUD) merupakan wahana pendidikan yang sangat fundamental dalam memberikan kerangka dasar terbentuk dan berkembangnya dasardasar pengetahuan, sikap dan keterampilan anak (Wahyudin, 2012: 6). Namun dalam proses pendidikan anak usia dini, guru biasanya menemukan berbagai perilaku anak. Periaku anak yang beragam sangatah tergantung darimana anak ini berasal.

Keluarga merupakan lingkungan pertama bagi seorang anak dalam mempelajari berbagai macam hal yang tidak pernah diketahui sebelumnya. Anak akan belajar untuk pertama kalinya melalui orang terdekatnya (orangtua). Ki Hajar Dewantara (Shochib, 1998:10) menyatakan bahwa keluarga merupakan pusat pendidikan yang pertama dan terpenting, karena sejak timbulnya peradaban manusia sampai sekarang keluarga selalu mempengaruhi pertumbuhan budi pekerti tiap-tiap manusia. Lingkungan keluarga merupakan tempat di mana seorang anak berinteraksi untuk pertama kalinya. Dalam keluarga anak mendapat rangsangan dalam pertumbuhan maupun perkembangannya, baik biologis maupun psikologis. Dalam proses belajar inilah, seorang anak akan mencontoh apa yang diajarkan dan dilakukan oleh setiap anggota keluarga. Morisson (2016: 26) mengemukakan bahwa pembelajaran terjadi utamanya lewat modeling, observasi, keteladanan pengalaman dan pengaturan diri dengan melewati empat tahapan, yaitu: 1) Memperhatikan orang lain. 2) Memilih perilaku-perilaku tertentu untuk direproduksi. 3) Mengingat perilaku-perilaku yang diamati. 4) Mereproduksi ulang perilaku yang diamati. Hal ini merupakan momen penting dalam sebuah kehidupan anak kedepan.

Perilaku keluarga khususnya orangtua dalam menerapkan pola asuh terhadap anak akan berpengaruh pada proses tumbuh kembang anak terutama dalam membentuk kepribadian anak. Setiap orangtua mempunyai pola asuh tersendiri dalam mendidik anakanaknya, dan ini mempengaruhi perkembangan anak. Menurut Djamarah (2004: 67) mengungkapkan bahwa Setiap orang tua tentunya ingin yang terbaik bagi anak-anak mereka, keingginan ini kemudian membentuk pola asuh yang akan di tanamkan orangtua kepada anak-anak. Orangtua diharapkan mampu menerapkan pola asuh yang sesuai pada anak dengan memberikan contoh yang baik serta dukungannya kepada anak dalam mengembangkan bakat dan minat yang dimilikinya. Kepribadian anak akan menjadi baik atau tidak tergantung dari pola asuh yang diterapkan oleh orang tuanya. Damayanti (2019: 1) melakukan penelitian dan menyimpulkan bahwa ada pengaruh pola asuh orangtua terhadap perilaku sosial anak terbukti dengan melihat hasil pengamatan beberapa kategori perilaku sosial anak dengan beberapa kategori pola asuh orangtua, dengan rata-rata kategori berkembang sesuai harapan. 
Berdasarkan fakta di lapangan, orangtua cenderung banyak menuntut dari anak. Khususnya pada anak usia dini (PAUD) orangtua cenderung bersikap otoriter dan menuntut anak untuk pintar dalam CALISTUNG (baca, tulis dan hitung). Orangtua tidak segan-segan untuk memaksakan anak dengan berbagai cara untuk anak menguasai CALISTUNG. Orangtua cenderung memaksa guru untuk mengajarkan anak CALISTUNG sebagai syarat ketika anak lulus PAUD bahkan orangtua memaksakan anak untuk mengikuti pelajaran tambahan (les) guna menguasai CALISTUNG dalam waktu yang relatif singkat. Orangtua merasa bangga jika anak pada usia PAUD memiliki kognitif yang baik walau dalam situasi memaksa. Hal ini dapat memberikan dampak negatif pada anak. Masih banyak orangtua yang menerapkan pola asuh yang tidak sesuai kepada anak, sehingga perilaku anak akan terbentuk ke hal yang tidak dirapkan.

\section{B. Pembahasan}

\section{Pola Asuh Orang Tua}

Pola asuh orangtua merupakan segala bentuk dan proses interaksi yang terjadi antara orangtua dan anak yang merupakan pola pengasuhan tertentu dalam keluarga yang akan memberi pengaruh terhadap perkembangan kepribadian anak (Baumrind dalam Rahman, 2012: 48).

Menurut Petranto (Suarsini, 2013) pola asuh orangtua merupakan pola perilaku yang di terapkan pada anak bersifat relatif konsisten dari waktu ke waktu. Pola perilaku ini di rasakan oleh anak, dari segi negatif maupun positif. Pola asuh yang di tanamkan tiap keluarga berbeda, hal ini tergantung pandangan dari tiap orang tua. Desmita (2013: 47) menjelaskan bahwa pola asuh orangtua itu sendiri adalah suatu cara terbaik yang dapat ditempuh orang tua dalam mendidik anaknya sebagai wujud dari rasa tanggung jawab kepada anak.

Jadi dapat disimpulkan bahwa, pola asuh orangtua adalah suatu cara dan upaya orangtua dalam mengasuh dan membimbing anaknya secara konsisten dengan tujuan membentuk watak, kepribadian, dan memberikan nilai-nilai bagi anak untuk dapat menyesuaikan diri dengan lingkungannya.

Menurut Edward (2006: 56) Pola asuh orangtua dipengaruhi oleh beberapa faktor diantaranya pendidikan orangtua, lingkungan, dan budaya. Dalam lingkungan keluarga, anak akan mempelajari dasar-dasar perilaku yang penting bagi kehidupannya kemudian

Pola asuh orangtua sangat bervariasi, dalam teorinya Diana Baumrind dalam Santrock, (2002: 257) pola asuh orangtua meliputi dua hal, yaitu penerimaan orangtua (parental responsiveness) dan tuntutan orangtua (parental demandingness). Penerimaan orangtuaadalah seberapa jauh orangtua merespon kebutuhan anak dengan cara yang bersifat menerima dan mendukung. Sedangkan tuntutan orangtua adalah seberapa jauh orangtua mengharapkan dan menuntut tingkah laku bertanggung jawab anaknya. Pola pengasuhan orangtua terhadap anak dibagi menjadi tiga tipe yaitu: Otoriter (authoritarian), autoritatif (authoritative), dan permisif (permissive). Adapun penjelasannya sebagai berikut:

\section{a. Pola Asuh Otoriter (Authoritarian)}

Pola asuh otoriter adalah bentuk pola asuh yang menekankan pada pengawasan orangtuaagar anak tunduk dan patuh. Orangtua yang memiliki pola asuh otoriter bersikap pemaksa, keras dan kaku dimana orangtua akan membuat 
berbagai aturan yang harus dipatuhi oleh anak-anaknya tanpa mau tahu perasaan sang anak. Orangtua akan emosi dan marah jika anak melakukan hal yang tidak sesuai dengan yang diinginkan oleh orang tuanya.

Bentuk pola asuh otoriter memiliki ciri-ciri orangtua bertindak tegas, suka menghukum, kurang memberikan kasih sayang, kurang simpatik, memaksa anak untuk patuh terhadap peraturan, dan cenderung mengekang keinginan anak. Selain itu pola asuh otoriter penerimaan (responsiveness) rendah dan tuntutan (demandingness) orangtua tinggi. Kecenderungan pola asuh otoriter menyebabkan anak kurang inisiatif, menjadi tidak disiplin, cenderung ragu, dan mudah gugup. Anak laki - laki dengan pola asuh otoriter memiliki kemungkinan untuk berperilaku agresif. Odebunmi (2007, dalam Okorodudu, 2010) mengungkapkan bahwa hasil dari beberapa laporan penelitian yang telah dilakukan menunjukkan sebagian besar dari semua kenakalan remaja berasal dari rumah yang orang tuanya kurang memiliki cinta dan perhatian. Perhatian, cinta dan kehangatan tidak ada dalam membantu perkembangan emosional dan penyesuaian pada anak. Rahayu dkk (2008). Seringkali anak dengan pola asuh otoriter tidak merasakan kebahagiaan, merasa ketakutan, merasa minder jika dibandingkan dengan orang lain, tidak mampu memulai aktivitas, serta kemampuan komunikasinya tergolong rendah. Pola asuh otoriter ini dapat menimbulkan akibat hilangnya kebebasan pada anak, inisiatif dan aktivitasnya menjadi kurang, sehingga anak menjadi tidak percaya diri pada kemampuannya. Dari pendapat diatas dapat disimpulkan bahwa pola asuh otoriter adalah cara pengasuhan yang bersifat mengekang, membatasi dan berkuasa juga mengatur apapun yang dilakukan anak. Biasanya orangtua menggunakan ancaman atau perintah yang harus dipatuhi oleh anaknya. Pola asuh otoriter ditandai dengan ciri orangtua yang bersikap sering memusuhi anaknya, menguasai, memukul, sering membentak, mengekang, sering mencaci-maki dan sering memarahi dan menuntut

\section{b. Pola Asuh Autoritatif / Demokratis (Authoritative)}

Orangtua yang memiliki pola asuh autoritatif ini berusaha mengarahkan anaknya secara rasional, berorientasi pada masalah yang dihadapi, menghargai komunikasi yang saling memberi dan menerima, menjelaskan alasan rasional yang mendasari tiap-tiap permintaan atau disiplin tetapi juga menggunakan kekuasaan bila saling menghargai antara anak dan orang tua, memperkuat standar-standar perilaku. Orangtua tidak mengambil posisi mutlak, tetapi juga tidak mendasarkan pada kebutuhan anak semata. Pola asuh autoritatif sering juga disebut dengan pola asuh demokratis. Pola asuh demokratis menitikberatkan pada tujuan tidak mengambil posisi mutlak, tetapi juga tidak mendasarkan pada kebutuhan anak semata. dan mengizinkan anak bersikap individualis. Orangtua yang demokratis biasanya bersikap penuh dengan pertimbangan, penuh dengan kesabaran, dan mencoba memahami perilaku anak. Pengawasan dilakukan tegas tetapi tidak membatasi dan terkontrol dengan tujuan untuk meningkatkan tanggung jawab pada anak agar lebih mandiri. Orangtua cenderung melibatkan anak-anak dalam pengambilan keputusan pada lingkup keluarga dengan cara berdiskusi, musyawarah, dan dialog. Pola asuh autoritatif mencirikan adanya keseimbangan antara hak dan kewajiban orangtua dan anak. Sehingga keduanya saling melengkapi, anak dilatih untuk bertanggung jawab dan menentukan perilakunya sendiri agar berdisiplin. Pola asuh autoritatif ini penerimaan (responsiveness) dan tuntutan (demandingness) kepada anaknya sama-sama tinggi

Pola asuh demokratis menurut Madyawati (2016:37-39) adalah pola asuh yang memprioritaskan kepentingan anak, tetapi tidak ragu-ragu mengendalikan mereka. Orangtua dengan perilaku ini bersikap rasional selalu mendasari 
tindakannya pada rasio atau pemikiran. Umairoh (2018: 11) mengungkapkan bahwa pola asuh orang tua yang demokratis akan menghasilkan anak yang optimal dalam pembentukan karakter kemandiriannya, sebaliknya orang tua yang menunjukkan sikap permisisf dana otoriter akan menghambat pada pembentukan kemandirian anak usia dini.

\section{c. Pola Asuh Permisif (Permissive)}

Pola asuh gaya permisif ini disebut juga pemurah karena orangtua tergolong demikian adalah orangtua yang memberikan kebebasan kepada anak untuk bergerak, tidak terlalu banyak menuntut atau melarang anak. Orangtua yang pemurah adalah orangtua yang hangat, suka merawat dan terlibat dengan anak, tetapi tetap mengontrol anak walaupun tidak terlalu ketat, umumnya toleran terhadap perilaku anak dan jarang menghukum anak. Pola asuh permisif mencirikan orangtua yang memberikan kebebasan sebebas-bebasnya kepada anak sehingga dapat menyebabkan anak kurang memiliki tanggung jawab dan anak dapat berbuat sekehendak hatinya tanpa pengontrolan orang tua. Pola asuh permisif antara penerimaan (responsiveness) orangtua terhadap anak tinggi sedangkan tuntutan (demandingness) terhadap anak rendah.

Dari berbagai macam pola asuh tersebut diatas, tidak ada bentuk pengasuhan yang benar atau salah, hanya saja dampak atau pengaruh dari bentuk pola asuh itu yang akan menentukan suatu pribadi yang berbeda-beda. Setiap pola asuh yang ditterapkan oleh setiap orangtuapasti berbeda-beda dan juga berdampak berbeda pula terhadap kepribadian anak.

\section{Perilaku Anak}

Menurut (Drajat, 2005) mengungkapkan bahwa, pengertian perilaku tidak dapat dilepaskan dari kaitannya dengan sikap. Sebaliknya dapat dikemukakan bahwa sikap berkaitan dengan tujuan memahami kecenderungan-kecenderungan perilaku. Menurut Gunarsa (2013) "Perilaku adalah segala sesuatu atau tindakan yang sesuai dengan nilai-nilai tatacara yang ada dalam suatu kelompok".

Mursid (2016: 35) mengungkapkan bahwa terdapat jenis perilaku yakni perilaku akrab. Bentuk dari perilaku akrab anak di tunjukan dengan memberikan rasa kasih sayang kepada guru dan teman. Mereka memperlakukan guru sebagaimana layaknya orang tua mereka sendiri. Seperti, memeluk, merangkul, memegang tangan dan banyak bertanya pada guru.

Hurlock (1991: 204) mengklasifikasikan pola perilaku sosial pada anak usia dini sebagai berikut:

a. Meniru, anak meniru sikap dan perilaku yang ia kagumi. Anak mampu meniru perilaku orang tua atau guru sesuai dengan yang dilihat anak.

b. Persaingan, yaitu keinginan untuk mengungguli dan mengalahkan orang lain.

c. Kerja sama, anak mulai bermain secara bersama dan bersifat koperatif dan Simpati, hanya timbul pada setelah usia tiga tahun. Semakin banyak interaksi dengan teman bermain maka anak akan dapat memiliki rasa simpati.

d. Empati, anak-anak dapat memiliki rasa empati pada masa kanak-kanak akhir.

e. Dukungan sosial, menjelang berakhirnya awal masa kanak-kanak dukungan dari teman sebaya menjadi lebih penting daripada persetujuan orang dewasa.

f. Membagi, anak mengetahui bahwa salah satu cara untuk memperoleh persetujuan sosial ialah dengan berbagi barang miliknya, terutama mainan. Mereka rela berbagi 
hanya untuk mempertebal tali pertemanan dan menunjukan identitas keakraban antar mereka.

Selain itu Rohayati (2013: 135) mengungkapkan bahwa pola perilaku yang tidak sosial adalah perilaku yang ciri-cirinya sebagai berikut:

a. Negativisme.

Negativisme adalah perlawanan terhadap tekanan dari pihak lain untuk berperilaku tertentu. Ekspresi fisiknya mirip dengan ledakan kemarahan, tetapi secara setahap demi setahap diganti dengan penolakan lisan untuk menuruti perintah.

b. Agresi.

Agresi adalah tindakan permusuhan yang nyata atau ancaman permusuhan. Biasanya tidak ditimbulkan oleh orang lain.

c. Pertengkaran.

Pertengkaran merupakan perselisihan pendapat yang mengandung kemarahan yang umunya dimulai apabila seseorang melakukan penyerangan yang tidak beralasan.

d. Mengejek dan menggertak. Mengejek merupakan serangan secara lisan terhadap orang lain, sedangkan menggertak merupakan penyerangan serangan yang bersifat fisik.

e. Perilaku yang sok kuasa.

Perilaku ini adalah kecenderungan untuk mendominasi orang lain atau menjadi "majikan".

f. Egosentrisme.

Hampir semua anak memiliki sifat egosentrik. Dalam arti bahwa mereka cenderung berpikirdan berbicara tentang diri mereka sendiri.

g. Prasangka.

Landasan prasangka terbentuk pada masa kanak-kanak awal yaitu ketika anak menyadari bahwa sebagian orang berbeda dari mereka dala hal penampilan dan perilaku dan bahwa perbedaan ini oleh kelompok sosial dianggap sebagai tanda kerendahan. Bagi anak kecil tidaklah umum mengekspresikan prasangka dengan bersikap membedakan orang-orang yang mereka kenal.

h. Antagonisme jenis kelamin.

Ketika masa kanak-kanak berakhir, banyak anak laki-laki ditekan oleh keluarga lakilaki dan teman sebaya untuk menghindari pergaulan dengan anak perempuan atau memainkan "permainan anak perempuan.

Penyebab perilaku agresif pada anak, Wirawan (2009: 94-97) mengungkapkan bahwa terdiri dari sosial, personal, kebudayaan, situ-asional, sumber daya, media massa, dan kekerasan dalam rumah tangga. Davidoff mengungkapkan bahwa faktor-faktor penyebab anak berperilaku agresi: amarah, faktor biologis, kesenjangan generasi, lingkungan, peran belajar model kekerasan, frustrasi, frustrasi, proses pendisiplinan yang keliru (Nadhirah, 2017: 145,146). Hal ini sejalan dengan pendapat dari Knapp bahwa Lingkungan dan permasalahan perilaku anak memiliki keterkaitan. Anak yang berusia muda dengan lingkungan tempat tinggal dan pendapatan yang rendah terlihat memiliki pengalaman masalah perilaku dibandingkan dengan anak yang hidup dalam berkecukupan atau makmur (Arriani, 2014: 270).

\section{Diskusi}

Orangtua berhak memilih pola asuh yang sesuai dengan pribadi serta kondisi keluarga. Kebanyakan orangtua tidak menggunakan satu bentuk pola asuh sepenuhnya. Pola asuh disesuaikan dengan kondisi dan situasi yang sedang berlangsung atau situasional, namun setiap orangtua pasti memiliki kecenderungan pola asuh yang digunakan. Orangtua 
selalu menginginkan yang terbaik untuk anak, jadi pilihan pola asuh merupakan tindakan terbaik menurut masing-masing orang tua.

Hasnida (2014: 104-107) menyatakan bahwa orangtua otoriter adalah orangtua dengan pola asuh yang kaku, tanpa kehangatan, bimbingan, komunikasi, diktator dan memaksakan anak untuk selalu mengikuti perintah orangtua tanpa kompromi, selalu menuntut dan mengendalikan semata-mata karena kekuasaan dan tak jarang disertai hukuman fisik bila anak melanggar/tidak patuh. Dan pola asuh permisif menurut Hasnida (2014:104-107) adalah orangtua yang membolehkan apa pun yang diinginkan anak, ini bisa terjadi karena orangtua sangat cinta atau sangat acuh. Pola asuh permisif karena acuh membuat anak merasa tidak diinginkan, tidak dipedulikan sehingga menyebabkan anak mempunyai harga diri rendah dan merasa bukan bagian penting untuk orangtuanya. Wibowo (2012:75) menguraikan bahwa keberhasilan keluarga dalam mendidik anaknya sangat tergantung pada model dan jenis pola asuh yang diterapkan para orang tua.

Budiman dan Harahap (2015: 200) mengadakan penelitian hasilnya menunjukan bahwa dari 26 responden menerapkan pola asuh tidak otoritatif sebanyak 11 orang $(42,3 \%)$, tidak permisif sebanyak 15 orang $(57,7 \%)$, dan pola asuh tidak otoriter sebanyak 15 orang $(57,7 \%)$. Semua jenis pola asuh ada pengaruh terhadap perkembangan anak. Wibowo (2012:75) menguraikan bahwa keberhasilan keluarga dalam mendidik anaknya sangat tergantung pada model dan jenis pola asuh yang diterapkan para orang tua.

Hasil dalam penelitian dari Makagingge (2019: 115) menemukan bahwa pola asuh otoriter dan permisisf berpengaruh negatif dan pola asuh demokratis berpengaruh positif terhadap perilakau sosial anak. Dalam penelitian ini menghasilakan nilai koefisien determinasi sebesar 0,726 atau 72,6\%. Asri (2018: 8) menyimpulkan dalam penelitian pada 42 siswa yang ada pada TK Kuntala Dewi III bahwa terdapat hubungan antara pola asuh otoriter, demokratis, dan permsisif dengan perkembangan nilai moral, sosial emosional, bahasa, kognitif, dan fisik motorik jika dilakukan pengujian secara kelompok, (2) dari tiga pola asuh, pola asuh yang memiliki hubungan yang sangat tinggi yaitu pola asuh demokratis. Dengan demikian dapat diartikan pola asuh demokratis berpengaruh terhadap perkembangan moral agama, soasial emosional, bahasa, kognitif, dan fisik motorik.

Nauli dkk, (2019: 250) menyimpulkan dalam penelitian studi kasusnya di Kota Bekasi bahwa perkembangan moral anak sangat dipengaruhi oleh ada atau tidaknya, tepat atau tidaknya suatu aturan, hukuman yang mendidik, penghargaan/reward, dan penggunaan tehnik disiplin yang diberikan oleh ibu. Intervensi yang lembut oleh ibu dapat mengarahkan kembali anak dan menarik perhatian positif dari anak. Ibu perlu diberikan arahan dan pengetahuan mengenai pentingnya peran ibu bagi perkembangan moral anak saat ibu terlibat dalam kehidupan anak, tegas dan disiplin kepada anak, menyempatkan waktu untuk berinteraksi bersama anak, meskipun ibu sibuk bekerja di pasar. Peran lingkungan masyarakat harus memberikan pengaruh yang baik bagi anak dan juga masyarakat harus saling bahu-membahu untuk memperhatikan perilaku anak yang memiliki orang tua bekerja, agar perilaku moral anak tetap terbentuk baik di masyarakat meskipun orang tua sibuk bekerja.

Tidaklah salah bagi setiap orang tua dalam menerapkan pola asuh yang berbedabeda pada anak. Wiyani (2016:197) yang menyatakan bahwa tidak ada pola asuh yang paling baik diantara pola asuh yang disebutkan. Sebaiknya orangtua tidak hanya satu menerapkan pola asuh ketika mendidik anak, tetapi orangtua harus mampu mengkombinasikan dengan pola asuh yang lainnya. Guna, dkk.(2019: 251). Sebaiknya orang tua lebih memperhatikan dan memahami perilaku anak dan dampaknya pada anak dari pola asuh yang diterapkan. 
Berdasarkan kajian literatur, penulis dapat menyimpulkan bahwa setiap orang tua memiliki pola-pola tersendiri dalam mendidik atau mengasuh anaknya. Pola asuh yang dipilih serta diterapkan orangtua sangatlah berpengaruh bagi perilaku anak dimasa kini maupun dimasa yang akan datang. Pola asuh orangtua dapat diterapkan bergantian dari ketiga pola asuh yang dikaji dengan memperhatikan situasi dan kondisi serta karakteristik anak yang diasuh. Pada kasus-kasus tertentu orangtua dapat menerapkan pola asuh otoriter bagi anak yang agresif, begitupula sebaliknya orang tua dapat menerapkan pola asuh demokratis jika anak yang diasuh adalah anak yang penurut dan dapat diajak diskusi. Orangtua dapat menerapkan pola asuh permisif bagi anak yang telah mandiri (dewasa). Namun orangtua perlu dengan bijak dan seksama untuk memilih serta menetapkan pola asuh yang akan diterapkan bagi anak. Pola asuh yang direkomendasikan penulis dalam kajian ini adalah pola asuh demokratis. Hal ini berdasarkan pada efek dari penerapan pola asuh ini yakni: Anak yang diasuh dengan pola asuh domokratis membuat anak memiliki kemampuan sosialisasi yang baik, memiliki rasa percaya diri dan bertanggung jawab.

\section{Simpulan}

Kesimpulan yang diperoleh dari kajian leteratur tentang pola asuh terhadap perilaku anak adalah sebagai berikut:

1. Pola asuh orangtua berpengaruh pada perilaku anak.

2. Setiap orangtua berhak memilih pola asuh yang tepat bagi anaknya dengan memperhatikan karakteristik anak, situasi dan kondisi yang dialami anak, namun dengan memperhatikan konsekuensi dari penerapan ketiga pola asuh orang tua, maka dianjurkan untuk orangtua agar menerapkan pola asuh demokratis bagi anak. 


\section{DAFTAR PUSTAKA}

Arriani Farah, 2014. Perilaku Agresif Anak Usia Dini. Jjurnal Pendidikan Usia Dini Volume 8 Edisi 2, November 2014

Asri IGA A Sri (2018). Hubungan Pola Asuh Terhadap Perkembangan Anak Usia Dini, Jurnal Ilmiah Sekolah Dasar, Vol. 2, No. 1, Tahun 2018, pp. 1-9

Budiman, Tapiana Sari Harahap. 2015. Pengaruh Pola Asuh Orang Tua terhadap Perkembangan Anak Usia Dini (Studi Kasus di PAUD Al-Muhajirin Desa Cibodas Pacet Cianjur). ISBN 978979-3541-50-1 IRWNS 2015

Desmita. 2013. Psikologi Perkembangan Peserta Didik. Bandung: PT RemajaRosdakarya.

Damayanti Fila. 2019. Pengaruh Pola Asuh Orang Tua Terhadap Perilaku Sosial Anak Di Kelompok B1 TK Kemala Bhayangkari 01 Pim Staf Besusu Tengah. Artikel Mahasiswa Program Studi PG PAUD, Jurusan Ilmu Pendidikan, Fakultas Keguruan dan Ilmu Pendidikan, Universitas Tadulako, No. Stambuk: A 41113008

Edwards, C. D. 2006. Ketika Anak Sulit Diatur. Bandung: Mizan Media Utama

Fuad Ihsan. 2001. Dasar-Dasar Kependidikan. Jakarta: PT Rineka Cipta.

Guna Melinda Sureti Rambu, Tritjahjo Danny Soesil, Yustinus Windrawanto.2019. Pengaruh Pola Asuh Orang Tua Terhadap Kemampuan Pengambilan Keputusan Mahasiswa Pria Etnis Sumba Di Salatiga. Jurnal Psikologi Konseling Vol. 14 No. 1, Juni 2019

Hasnida. 2014. Analisis Kebutuhan Anak Usia Dini. Jakarta : Luxima.

Hurlock Elizabeth B. 1991. Psikologi Perkembangan : Suatu Pendekatan Sepanjang Rentang Kehidupan Jakarta: Erlangga

Hasan, Maimunah. Pendidikan Anak Usia Dini, Yogjakarta: Diva Press, 2009.

Madyawati, Lilis. 2016. Strategi Pengembangan Bahasa Pada Anak. Jakarta: Prenadamedia Group.

Morisson. 2016. Pendidkan Anak Usia Dini Saat Ini. Yogyakarta: Pustaka Belajar.

Nadhirah Yahdinil Firda, 2017. Perilaku Agresi Pada Anak Usia Dini Jurnal Pendidikan Anak Usia Dini, Vol. 2 No. 2, Juli - Desember 2017. ISSN 2541-5549.

Nauli Vienna Aniella, Karnadi, Sri Martini Meilani. 2019. Peran Ibu Pedagang Pasar 24 Jam Terhadap Perkembangan Moral Anak (Penelitian Studi Kasus di Kota Bekasi) Jurnal Obsesi : Jurnal Pendidikan Anak Usia Dini Volume 3 Issue 1 (2019) Pages 241 - 253, DOI: 10.31004/obsesi.v3i1.179

Rohayati Titing 2013. Pengembangan Perilaku Sosial Anak Usia Dini. Cakrawala Dini : Vol. 4 No. 2, November 2013

Rahayu dkk. 2008. Hubungan Pola Asuh Orangtuadengan kesehatan Mental Remaja. jurnal keperawatan unpad (Nursing Journal of Padjajarar University), 10 (18)

Rahman, U. 2009. Karakteristik Perkembangan Anak Usia Dini. Karakteristik Perkembangan Anak Usia Dini 
Shochib Moh. 1998. Pola Asuh Orang Tua. Rineka Cipta: Jakarta

Santrock, J. W. 2002. Life-Span Development Perkembangan Masa Hidup, Edisi Kelima. Terj. Juda Dumanik dan Achmad Chusairi. Jakarta: Erlangga.

Suarsini, Desy. 2013. Pola Asuh Orang Tua, Artikel (online) (http;//dessuar.blogspot.com, diakses 10 Maret 2020)

Umairoh Siti, 2018. Perbedaan Pola Asuh Orang Tua Terhadap Kemandirian Anak, Golden Age Jurnal Ilmiah Tumbuh Kembang Anak Usia Dini, Vol. 3 No. 3 September 2018

Wahyudin, Uyu. 2012. Penilaian Perkembangan Anak Usia Dini. Bandung : PT Perika Anditama

Wiyani, Novan Ardy. 2016. Konsep Dasar Paud. Yogyakarta : Gava Media. Wirawan, Sarlito. Psikologi Sosial. Jakarta: Salemba Humanika, 2009.

Wibowo, Agus. 2012. Pendidikan Karakter Anak Usia Dini. Yogyakarta : Pustaka Pelajar. 